\title{
An Analysis of EIA Report of the Second International Airport Project, Nepal
}

\section{Shree Govind Shah}

\begin{abstract}
Environmental Impact Assessment (EIA) is a planning tool which enables decision makers to accept environmentally friendly projects and reject environment damaging projects or their certain components. EIA has been mandatory in Nepal since the enactment of Environment Protection Act in 1997. Usually in Nepal, EIA is done for a project late in the project cycle after many important decisions on design and locations have already been made. While in case of government sponsored projects, EIA has remained as 'pro forma' compliance with government's legal requirements. This paper analyses outputs of approved EIA of a mega infrastructure project "Second International Airport Project" which government wants to implement despite of protests by conservationists, and environmental and social activists. There are technocratic problems in EIA Report such as informational weaknesses, insufficient analysis of impacts, and inadequately proposed mitigations measures. It indicates political influence on EIA. This paper suggests making policy decision on size and nature of an international airport and its facilities, alternative locations avoiding ecologically sensitive area, and source of funding. It proposes to conduct a comprehensive Environmental and Social Impact Assessment (ESIA) complying with national and international environmental and social safeguards, before making any decision to fell trees.
\end{abstract}

Keywords: Ecosystem services, pro Forma, technocratic problems, buffer zone, endangered, national park, livelihoods, replacement, compensatory plantation, biodiversity, conservation, Nepal

\section{BACKGROUND}

$\mathrm{G}$ overnment of Nepal is planning to construct International Civil Aviation Organization (ICAO) standard, Second International Airport. A prefeasibility study conducted in 1995 identified 8 sites and the feasibility study in 1997 selected the present site in Kohalbi Municipality (GEOCE, 2018). The then Ministry of Environment on 10 February 2011, approved Terms of Reference (TOR) for Environmental Impact Assessment (EIA) study as required by government legislation. Ministry of Culture, Tourism and Civil Aviation (MoCTA) is the responsible government agency, the proponent to construct and operate the airport.

The Nepalese Consulting firm GEOCE Consultants (P) Ltd., located in Lalitpur, Nepal prepared EIA Report of the Second International Airport Project (SIAP) for the proponent MoCTA in March 2018 based on given TOR and following procedures of Environment Protection Rules (1997) of Government of Nepal and MoCTA submitted the EIA Report with recommendation for approval to the Ministry of Forests and Environment (MoFE), the latter approved the submitted EIA Report for its implementation on 23 May 2018 (KP, 2018).

Some environmental, conservation and social activists have been publicly expressing their worries and campaigning against the felling of about 2.4 million trees that would have a significant adverse impact on forest ecology, wildlife and ecosystem services, and asked the government to block the project on environmental ground and select another site for SIA (THT, Sept 2018, Hakahaki, Sept 2018, Rai June 2018 \& others). However, the Proponent MoCTA is determined to construct the airport and has requested the MoFE to approve felling of about 0.8 million trees in the first phase as per the approved EIA Report (Hakahaki, Sept 2018).

EIA is a project-planning and decision-making instrument which facilitates decision makers to accept environment friendly projects and reject environmentally damaging projects or their certain components (Robinson, 1992; IAIA, 1995; Hironaka, 2002). Effects of EIA on projects have been very weak and have played only limited role in project approval and design decisions; it has remained as 'pro forma' compliance with legal requirements (IAIA, 1995; Cashmore et al, 2004). Politically motivated EIAs are becoming common in developing countries. Decisions are often skewed towards non-environmental values. However, there are examples of significantly influencing decision-making process such as withdrawal of environmentally unsound projects, faulty locations etc. or even blockage of projects (van de Grondane, 1994; Devlin JF and Nonita TY, 2008). In Nepal, there is no such example of a blocked project due to EIA.

This paper is a technical evaluation of the Environment Impact Assessment (EIA) Report of the Second International Airport Project (SIAP) prepared by the Proponent MoCTA and approved for implementation by MoFE; both government agencies. This is the first time a technical evaluation of an approved EIA is being done in Nepal. This paper examines the outputs of EIA report, analyses technocratic problems and EIA usefulness, and suggests steps need to be focussed in next stage of a comprehensive EIA.

Data and information provided in the approved EIA report are analysed. Besides, published information on 
the Second International Airport Project were gathered from newspapers, magazines and social media, also, published papers in journals and documents relevant to EIA process and usefulness are reviewed.
EIA report. It discusses the major findings, identifies technocratic problems, and suggests steps that need to be focussed in the next stage of EIA and 'detailed design phase study'.

\begin{tabular}{|c|c|c|c|}
\hline SN & Components & Details & Comments by author \\
\hline 1 & \multicolumn{2}{|c|}{ Construction of ICAO standard international airport } & \\
\hline 1.1 & $\begin{array}{l}\text { Construction of Runway } \\
\text { and Taxiway }\end{array}$ & $\begin{array}{l}\text { Phase } 1 \text { (2020-2030): } 3.6 \mathrm{~km} \text { long one runway \& two } \\
\text { taxi ways } \\
\text { Phase 2: altogether } 3.6 \mathrm{~km} \text { long two parallel runways \& } \\
4 \text { taxi ways }\end{array}$ & $\begin{array}{l}\text { Timeframe for } 2 \text { nd phase is not given; To be de- } \\
\text { cided during 'Detailed Design Phase (DDP)' }\end{array}$ \\
\hline 1.2 & $\begin{array}{l}\text { Construction of passenger } \\
\text { and cargo terminals }\end{array}$ & $\begin{array}{l}\text { Phase 1: capacity to handle } 9 \text { million passenger/yr - } \\
25,000 / \text { day } \\
\text { Phase 2: capacity to handle } 60 \text { million passenger/yr - } \\
\text { about } 167,000 \text { /day }\end{array}$ & $\begin{array}{l}\text { 2nd phase passenger handling capacity appears to } \\
\text { be too high, } 60 \text { million/yr. Needs to be sensibly } \\
\text { worked out during policy dession and DDP }\end{array}$ \\
\hline 1.3 & $\begin{array}{l}\text { Construction of airport } \\
\text { facilities such as aircraft } \\
\& \text { GSE maintenance com- } \\
\text { plex, car parks etc }\end{array}$ & Size of facilities in Phase $1 \&$ Phase 2 is given & $\begin{array}{l}\text { Size of airport facilities and airport utilities in } \\
\text { 2nd phase has been calculated on the assump- }\end{array}$ \\
\hline 1.4 & $\begin{array}{l}\text { Construction of airport } \\
\text { utilities }\end{array}$ & $\begin{array}{l}\text { - Power Plant, Airfield lighting substations, Heating/ } \\
\text { cooling plant \& airport fuelling facilities } \\
\text { - Pumping station and water treatment plant } \\
\text { - Sewage treatment plant \& solid and hazardous facility }\end{array}$ & $\begin{array}{l}\text { or } 164,000 / \text { day. Government should make policy } \\
\text { decision to fix a comfortable size of the SIA in } 2 \text { nd } \\
\text { phase }\end{array}$ \\
\hline & Area required & $\begin{array}{l}\text { Government has declared } 8,046 \text { ha as 'Airport Area'. As } \\
\text { per EIA report the total land required for Phase } 1 \text { work } \\
\text { (airport with one runway and its facilities) is } 1,084 \text { ha } \\
\text { and in total } 1,300 \text { ha for phase } 2 \text { work which include an } \\
\text { additional parallel runway and other facilities. Airport } \\
\text { city would cover } 600 \text { ha. }\end{array}$ & $\begin{array}{l}\text { Airport and facilities including Airport City would } \\
\text { cover would use about } 24 \% \text { of the declared 'Air- } \\
\text { port Area'. Open space and buffer area is } 3 \text { times } \\
\text { more than built-in area. Government must decide } \\
\text { size of the buffer area. }\end{array}$ \\
\hline 2 & Airport City development & $\begin{array}{l}\text { Modern transportation, communication, water supply, } \\
\text { drainage and provisions of hotel and residential facili- } \\
\text { ties; all covering } 600 \text { ha. }\end{array}$ & $\begin{array}{l}\text { EIA report does not have any assessment of the } \\
\text { proposed airport city; no rationale for this city. }\end{array}$ \\
\hline 3 & Construction materials & $\begin{array}{l}\text { EIA estimates huge requirements of construction } \\
\text { materials for the project: } 8.36 \text { million mt of earth fill } \\
\text { materials, sub-grades, aggregates, sand and boulders for } \\
\text { the Phase } 1 \text { single runway construction. } \\
\text { EIA report has suggested upstream of Pasaha Khola and } \\
\text { Lal Bakaiya River as source for construction material. } \\
\text { EIA mentions that detail requirement of construction } \\
\text { materials will be worked out during DDP. }\end{array}$ & $\begin{array}{l}\text { There is lack of technical information on construc- } \\
\text { tion materials requirement for various works in } \\
\text { Phase } 1 \text { and Phase } 2 \text {. } \\
\text { There is no environmental assessment of quarry } \\
\text { sites. }\end{array}$ \\
\hline 4 & Construction planning & $\begin{array}{l}\text { The Second International Airport (SIA) is proposed to } \\
\text { be built in } 4 \text { stages with serving passenger volume of } \\
4.8 \text { million pax, } 6.7 \text { million pax, } 9.2 \text { million pax and } 60 \\
\text { million pax. } \\
\text { Details will be prepared during DDP. }\end{array}$ & $\begin{array}{l}\text { EIA is not clear about these } 4 \text { stages of construc- } \\
\text { tion planning. In some chapters, EIA mentions } 3 \\
\text { phases. }\end{array}$ \\
\hline 5. & Construction facilities & $\begin{array}{l}\text { EIA does not have detailed description on connecting } \\
\text { roads, mechanical yards, aggregate crushing and mixing } \\
\text { facility, construction materials storage yards, spoil and } \\
\text { waste disposal area, Construction camps etc. EIA sug- } \\
\text { gests careful planning of these infrastructure facilities } \\
\text { and details to be worked out during DDP. }\end{array}$ & $\begin{array}{l}\text { EIA has not done environmental assessment of } \\
\text { infrastructure facilities required during construc- } \\
\text { tion and operation phases. }\end{array}$ \\
\hline & Project Cost & $\begin{array}{l}\text { EIA cited total cost US } \$ 6,565 \text { million which is based } \\
\text { on } 2010 \text { estimates: US } \$ 545 \text { million for phase } 1 \text {, US } \\
\$ 2,553 \text { million for phase } 2 \text { and US } \$ 3,467 \text { million for } \\
\text { phase } 3 \text {. This is based on } 2010 \text { price. }\end{array}$ & $\begin{array}{l}\text { Considering inflation rate of } 6-7 \% \text { project cost for } \\
\text { Phase } 1 \text { would be around US } \$ 900 \text { million }\end{array}$ \\
\hline
\end{tabular}

Table 1: Project components as described in EIA Report

This paper provides a brief background of the technical analysis, summarises salient features of the project with its rationale and environmental conditions in the project area, and environmental impacts and mitigation measures as mentioned in the approved

\section{SALIENT FEATURES OF SIAP}

\section{Project Rationale}

International air connectivity to Nepal is confined only to the Tribhuvan International Airport (TIA) in Kathmandu Valley of Nepal. It is very congested and 
there is no space for its expansion due to haphazard urbanization and topographical limitations. A good moderate tourism growth would require Airport to handle 3-4 million passengers per year while TIA handles about 1.1-1.3 million passengers per year. Airspace management for take-off and landing planes has become a serious problem. NEPECO/IRAD/BDA study in 1997 stated that TIA could not meet the rising demands of tourist arrival in Nepal after 2015 (GEOCE, 2018).

\section{Project Description}

The Second International Airport Project (SIAP) proposed (a) construction of an ICAO standard international airport with required airport facilities and utilities such as two parallel $3.6 \mathrm{~km}$ long runways, taxiways, passenger and cargo terminals, aircraft maintenance complex and other utilities (Table 1), and (b) airport city development with all the facilities of modern transportation, communication, water supply, drainage and provisions of hotel and residential facilities adjacent to international airport.

\section{Project Location}

The proposed SIA area is in Kohalbi Municipality which was formed in 2016 in Bara District of Province 2, southern Nepal, while Nijgadh is the adjoining Municipality. Approximately, the site is trapezoidal in shape, occupying $80.5 \mathrm{sq} \mathrm{km}$ area (longitude $85^{\circ} 4^{\prime} 24^{\prime \prime}$ to $85^{\circ} 12^{\prime} 38^{\prime \prime}$ and latitude $27^{\circ} 6^{\prime} 38^{\prime \prime}$ to $27^{\circ} 10^{\prime} 39^{\prime \prime}$ ). A location map of the proposed SIA project is presented in Fig 1.

East-West Highway runs parallel to the project area in the north. Government has initiated construction of Kathmandu-Terai Fast Track-Express Highway as a prerequirement of the SIAP operation. Government has awarded Korean JV to prepare 'Detailed Project Report' of this expressway. Simra Airport, which provides regular air service to Kathmandu, is located about $10 \mathrm{~km}$ south of the proposed SIA while aerial distance from SIA site to Indian border is about $20 \mathrm{~km}$ in south direction.

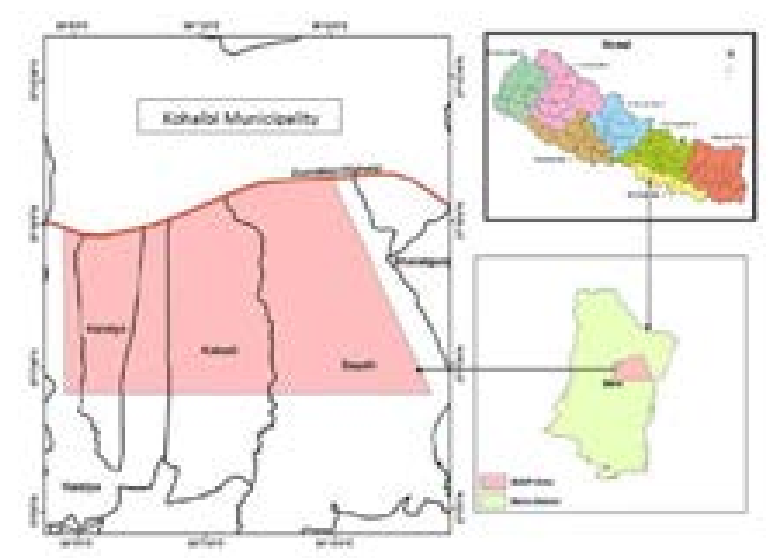

Fig 1: Location map of the proposed SIA project

\section{Project Area and Land Use Pattern}

Government has declared 8,046 ha in Kohalbi municipality as "Airport Area" which is heavily forested. According to EIA report, 7,587 ha (94.3\%) is forestland under the ownership of the Ministry of Forest and Environment followed by 296 ha flood plain, 76 ha registered private land and 87 ha under other land use. Kohalbi municipality, where this SIA project is proposed, occupies an area of $157.4 \mathrm{sq} . \mathrm{km}$ with a total population of 44,082 in 2011 (GON, 2018).

As per Terms of Reference for EIA, the proposed SIA Project requires 1,300 ha for airport with two parallel runways and its infrastructure / utilities and 600 ha for the airport city. The declared 'Airport Area' is considered as the direct impact area.

\section{EIA Rational and TOR/Methodology}

As per the Environment Protection Act (EPA) 1997 and schedule 2 of Environment Protection Rules (EPR) 1997 of the government of Nepal, 'Environmental Impact Assessment' is mandatory for the construction of new airport. The consultant GEOCE followed general methodology including public hearing as prescribed in EPR, 1997.

Comments: SIA is a huge infrastructure development project which would require investment from national and international financial institutions. Under this context EIA should have followed environmental and social safeguards policies, strategies and norms and codes prescribed by international financial agencies such as ADB, World Bank, IFC or others. EIA study team lacked specialists on faunal assessment and analysis of ecosystem services of the vast forest area, as well as assessment of aircraft noises and engine emissions, hazardous building materials and waste management, and other critical issues related to the construction of ICAO category International airport.

\section{ENVIRONMENTAL CONDITION IN THE PROJECT AREA}

The descriptions below are from the EIA Report, 2018

\section{Physical Environment}

The proposed SIA Project area is situated in the Gangetic alluvial plane with elevation of less than $300 \mathrm{~m}$ and it has flat plain topography. The climate is subtropical and humid and rainfall pattern is monsoonal. The braided Pasaha and Lal Bakaiya rivers originating in lower hills bring flash floods and sediments during monsoon; riverbank cutting is intense. There are small seasonal streams and drainages that collect seepage water, locally called 'Paini', in the project area and they join Pasaha and Lal Bakaiya rivers in downstream area. There is good source of groundwater in the project area which is used for irrigation and drinking. At present, there is no air or noise pollution. 


\section{Biological Environment}

The forest in the project area is broadly classified into: Sal Forest, Terai-Hardwood Forest and Khair-Sissoo Forest. Forests are mostly dominated by Sal (Shorea robusta) except on either side of the river banks where a riverine type of forest with Sissoo (Dalbergia sissoo), Khair (Acacia catechu) and other associates like Red Silk Cotton (Bombax ceiba), Lagerstroemia parviflora, Yellow Teak (Adina cardifolia), Asna (Terminalia tomentosa) are dominating. Sal forests are the economic forest resources of Bara district.

EIA describes the project area as one of the richest forest biodiversity area in Terai with considerably high Non-Timber Forest Products (NTFPs), and some of the NTFP species having high potential for marketing. EIA identified 22 NTFP species in the project area. Forest vegetation provides edible fruits such as Black Plum (Eugenia jambolana), Indian Gooseberry (Phyllanthus emblica), Bengal Quince (aegle marmelos), Red date (Ziziphus jujubae) etc., plants with medicinal uses, fibres for making ropes, leaves for making plates and others. At least 60 species recorded are edible.

About 30 ha are planted forest in Tangiya settlement area and about 350 ha of forests are leased to government owned Herbal Processing and Production Company Limited (HPPCL) which produces essential oils like Palma Rosa, Citronella, Mentha, Eucalyptus, etc.

Some forest area has been declared as 'Collaborative Forest (CF)' with silviculture system and their 'operation plan' has been prepared and approved by the District Forest Office about 5-6 years ago with validity of 10 years. These CFs provide forest products to people in their command area; the two Tamagadhi CF $(2,260$ ha) and Sahajnath CF (2,579 ha) have just over 37,000 beneficiary households.

\begin{tabular}{|c|c|c|}
\hline Forest vegetation & ha & Timber $\mathbf{~ m}^{\mathbf{3}}$ \\
\hline Forest area & 7,587 & \\
\hline Mature trees & $(585,499)$ & $(600,140)$ \\
\hline Shorea robusta & 198,450 & 198,049 \\
\hline Other species & 387,049 & 402,091 \\
\hline Pole sized trees & $1,864,820$ & - \\
\hline Regeneration -sapling/ha & 3,127 & - \\
\hline Regeneration -seedling/ha & 4,772 & - \\
\hline
\end{tabular}

Source: Data from EIA Report (2018) analysed.

Table 2: Forest vegetation in the proposed SIA Project area

Forest in project area has a medium density forest vegetation with 323 trees/ha (77 matured trees and 246 pole-sized trees), 3,127 saplings/ha and 4,772 seedlings/ ha (Table 2). There are 2,450,319 mature and pole-sized trees in the project area. Over $52 \%$ of the forest area is under the dominancy of Sal species; Sal Forests are the most economic forests in the district. Some part of the project forest is classified as protected forest.

The project area forms a continuous green corridor for wildlife; the newly extended parts of Parsa National Park (PNP) run almost along the northern border of the project area. The project area provides good feeding habitat for mammals and other wildlife; EIA reported 23 species of mammals, 31 avian species and 10 species of reptiles in and around the project area. Among wildlife species visiting forests in project area, Chinese pangolin (Manis pentadactyla), Himalayan Goral (Naemorhedus goral), leopard (Panthera pardus) and tiger (Panthera tigris) are nearly threatened and endangered mammal species; Lesser Florican (Sypheotides indicus) is an endangered bird species (IUCN, 2008).

Comments: Since the proposed project area is a part of Parsa National Park (PNP) 'buffer zone' and lies in Terai Arc Landscape (TAL), EIA should have analysed biodiversity and wildlife aspects of PNP and its contribution to TAL's conservation goal. According to Forest Rules (revised in 2001) Sal (Shorea robusta) and Satisal (Dalbergia latifolia) are protected species and trees are banned for transportation, export and felling

\section{Social Environment}

The proposed project area is in Ward no. 8 of Kohalbi Municipality, Bara district. There are three settlements established in the project area and as per EIA report, there are 7,487 people living in 1,492 households and together they cultivate about 530 ha land. They are migrant population -illegal encroachers of forests mostly from hills except living in Kathghat settlement. Migrant settlement do not possess land ownership certificates although they cultivate land.

Kathghat: is an old settlement of Tharu Indigenous community of Madhesh origin. There are 132 households and only 16 of them who do not have their land ownership paper are included in EIA.

Tangiya Basti: government resettled few hill migrants in 1980 s and more people have arrived since then; now there are more than 1,439 households settled by clearing forest area. They do not possess land rights.

Matiyani: is a newly established settlement - since 2003; the 39 families settled here belong to Dalit untouchable community of Madhesh origin. They do not possess legal documents for land.

They have developed shallow to deep tube-well irrigation system for growing vegetables as cash crops. The average landholding is about $0.33 \mathrm{ha} /$ households which is not enough to feed all the members in a household. Farmers practice intensive cultivation and 
grow cash crops; vegetables are grown in about $60 \%$ of the cropped area, followed by maize $15 \%$ and the rest $25 \%$ other crops.

They have built 1,494 residential structures, 49 of these buildings are categorized as Pakka - constructed using brick and cement, while the rest are Kachcha using wood and thatched/ zinc roof. There are four public primary schools and two private schools in the project settlements, average literacy is $73.5 \%$. There is a health centre in Kathghat and Tangiya basti settlements. Tubewells provide drinking water in all three settlements. There is no electricity supply line from the national grid but almost all households (90\%) use solar for lighting. About $70 \%$ use LP gas for cooking followed by $28 \%$ using fuelwood. Nijgadh town located 5-6 $\mathrm{km}$ from the project area is the nearest market centre.

There is a Sahajnath Shiv temple in the project area of regional significance. There are 7 smaller irrigation schemes sourced in the southern part of the project area which provide irrigation to 2,688 ha in more than 15 settlements.

Comments: EIA has not included all the households and their land who are permanently living in the project area for decades such as Tharu indigenous community in Kathghat settlement. It lacks livelihood analysis of people living in the proposed project area as well as outside the project area who depend on the project area for forest products and water source for irrigation.

\section{ENVIRONMENTAL IMPACTS AND PROPOSED MITIGATION MEASURES}

Project impacts and suggested mitigation measures summarised below are from the EIA Report, 2018

\section{Project Activities Causing Impacts}

(a) Construction and operation of an ICAO standard international airport in three phases,

Construction Phase Activity:

(i) Construction related activities e.g. land preparation for construction, aggregate crushing and mixing facility, construction materials storage yards, spoil and waste disposal area, construction camps, mining for construction materials etc.

(ii) Construction of 'Access and Peripheral' road (30 km $\mathrm{x} 20 \mathrm{~m}$ width) to project sites

\section{Operation Phase activity:}

i) Solid wastes, waste water - sewage, and other wastes generated in airport

ii) Landing and taking-off of large airplanes in the adjacent area of Parsa National Park

b) Development of Airport City adjacent to the airport

Terms of Reference for EIA states that the proposed SIA with two parallel runways would be developed in
1,300 ha and Airport City would cover 600 ha. However, government has demarcated and declared 8,046 ha as 'Airport Area' assuming the future development of SIA as the international hub for air traffic in South Asia and a possible 'defence airport' of the country. EIA has been prepared for the clearance of the entire 8,046 ha.

Comments: There is no sound reason for declaring 8,046 ha as airport area when infrastructure facilities and utilities for airport would require only 1,300 ha. Again, development of airport city at the cost of biodiversity rich forest is questionable.

\section{Beneficial Project Impacts}

Beneficial project impacts as per EIA Report are summarised here:

- Employment generation to local people during project construction and operation phase;

- Increase in local economy

- Technical skills and knowhow to local community

- Induce development in project municipality Kohalbi Municipality and surrounding areas

- Improvement in the national and international connectivity through air and motorable road

- Creation of new area of diverse business and industrial opportunities in the project area and its vicinity

- Opening of market for the locally produced agriculture products

- Opening of opportunity for diversification/ intensifications of agricultural activities for better economic returns to farmer communities

- Appreciation in the land values in the project vicinity

- Enhancement of social service facilities such as education, health water supply, electrification

- Impact on tourism

\section{Potential Adverse Impacts and Proposed Mitigations}

a) Physical Environment

Adverse Impacts

i) Land use changes and implication to the ecological balance of the area

- Removal of forest vegetation in the entire project area could cause ecological imbalance as well as adversely affect surface and groundwater in the southern part of the project area.

ii) Changes in drainage 'Paini' networks and implications to local runoff and erosion

- Construction activities could disturb natural drainage networks and their natural flow

iii) Change in air pollution level due to construction activities

iv) Change in the pollution level of surface water

- Dumping of construction wastes, haphazard disposal of liquid wastes from labour and other camp sites 
and leakage of petroleum products could pollute natural drains and surface water and affect water quality in downstream area

v) Changes in noise pollution level due to construction activities

vi) EIA has identified following adverse impacts during project operation

- Upstream erosion enhancement, flash floods and associated change in river course, and sedimentation could have implications to airport area

- Changes in surface and groundwater hydrology

- Emission from aircraft engines, ground support equipment, auxiliary power units, ground access vehicles would significantly increase air pollution in the project area. Aircraft engine emissions are major greenhouse gases which have great implications for climate change.

- Landing and take-off of aircrafts, and engine runups after aircraft maintenance produce maximum noise level of up to $90-110 \mathrm{~dB}(\mathrm{~A})$ on the surrounding environment. Its impacts would be noticeable within $2 \mathrm{~km}$ from the airport boundary.

\section{Mitigation Measures}

EIA has proposed the following mitigation measures to reduce impacts on physical environment:

- Conventional good practices for management of natural drainage system, disposal of construction and other wastes, operation of crusher and batching plants, leakage of oil/grease and other hazardous materials, landscaping in the project area, and control ofair, water and noise pollution during construction phase.

- Upstream erosion enhancement measures through river training, maintaining drainage channels in the project area, managing surface hydrology through minimum loss of forest cover and construction of wells/ditches north of the project area for groundwater recharge

- EIA hasrecommended to adopt ICAO 'policies and practices' related to environmental protection including air and noise pollution, and safety.

Comments: Southern part of the project area is partially the source of irrigation system that irrigates farming lands in the downstream areas. Changes in surface and groundwater hydrology in the project area would affect water source and irrigation system. Increased noise level could impact on wildlife adjacent to the project area and in Parsa National Park. EIA lacks environmental assessment of quarry sites.

b) Biological Environment

Three scenarios of project impacts are assessed in the EIA Report.

i) Forest vegetation loss in the 1stphase airport development
- The first phase airport development with $3.6 \mathrm{~km}$ long single runway including peripheral and approach roads (86 ha) would require 1,084 ha area. Forest area to be cleared is 990 ha, having 328,904 trees. The loss of forest product from these trees would be gross 1.68 million cubic foot timber and 4,703 Chatta fuelwood valued at NPR 8.5 billion (US $\$$ 77.3 million) at market price (Table 3 ).

ii) Loss of forest vegetation in the 2nd phase airport development

- Total area required for the full-fledged SIA in 2nd phase with capacity of serving 60 million passengers/year including airport city is 1,900 ha. EIA has estimated 1,641 ha forest land to be clearfelled. There will be permanent loss of 448.084 trees having gross 8.12 million cubic foot timber and 8,050 Chatta fuelwood. Its valuation at market price in 2018 was estimated to be NPR 14.9 billion (US \$ 135.4 million).

iii) Loss of forest vegetation in the whole 'direct impact area'

- Demarcated airport area is 8,045 ha, of which forest area occupies 7,582ha. EIA estimated 2.45 million standing trees(586,001 matured trees and $1,864,827$ pole sized trees) having 36.9 million cubic foot timber and 39,062 Chhatta fuelwood, currently valued at NPR 69.2 billion (US \$ 629 million)

\begin{tabular}{|l|c|c|c|}
\hline \multicolumn{1}{|c|}{ Description } & SIA Phase 1 & $\begin{array}{c}\text { SIA f full- } \\
\text { f I d g e d } \\
\text { Phase I \& 2 }\end{array}$ & $\begin{array}{c}\text { SIA Project } \\
\text { area }\end{array}$ \\
\hline Total area (ha) & 1,084 & 1,900 & 8,045 \\
\hline Forest area (ha) & 990 & 1,601 & 7,582 \\
\hline Other area (ha) & 94 & 299 & 463 \\
\hline Forest vegetation & 328,904 trees & 448,084 trees & $\begin{array}{c}2,450,827 \\
\text { trees }\end{array}$ \\
\hline - matured trees & 74,859 & 128,670 & 586,001 \\
\hline - pole-sized trees & 254,050 & 319414 & $1,864,827$ \\
\hline Forest product & & & \\
\hline - gross timber (cft) & 1.68 million & 8.12 million & 36.9 million \\
\hline $\begin{array}{l}\text { - Fuelwood (Chhat- } \\
\text { ta) }\end{array}$ & 4,703 & 8,050 & 39,062 \\
\hline $\begin{array}{l}\text { Valuation at market } \\
\text { price }\end{array}$ & & & \\
\hline NPR & 8.5 billion & 14.9 billion & 69.2 billion \\
\hline US \$ & 77.3 million & 135.4 million & 629 million \\
\hline
\end{tabular}

Source: EIA Report (2018) - data given are summarized. One Chatta is one truckload of fuelwood.

Table 3: Loss of Forest vegetation due to implementation of SIAP

Besides, two Forest Range Offices and one Ilaka Forest Office operating in the Project area will be displaced. 
iv) Loss of forest resources and its implication on livelihood of local community

- People living close to the project area in Kohalbi municipality will lose opportunity to collect various forest products such as fuelwood, indigenous medicinal herbs, wild fruits and seasonal wild vegetables, leaves, organic matter for compost, fodder and grazing for their ruminants. This may put pressure on other national forests and resources.

v) Loss of Collaborative Forest (CF) area

- People legally using CF for forest products will have to look for alternatives. Major parts of the two CFs are in the proposed project area.

- Associated impacts on forest resources identified in EIA are as follows:

- Impacts of workforce, associated economic migrants and airport city on forest resources during project construction and operation phase

- Loss of primary habitat in 80 sq. $\mathrm{km}$ of primary forest; higher chances of wildlife to be killed in the project area

- Impact of higher noise level on wildlife in the project area and adjoining forest area during construction and operation phase

- Forest fire hazard during construction phase

- A high possibility of bird hazard during operation phase.

\section{Mitigation Measures}

EIA has proposed the following mitigation measures to ameliorate project impacts on biological environment.

i) Compensatory plantation for the loss of forest vegetation

- EIA has suggested to make forest clearance only for the first phase airport infrastructures with one runway which would require to clear fell 990 ha of forest land (Table 3). About 8.2 million saplings will be planted in 5,139 ha of land to compensate loss of 328, 904 standing trees.

- EIA has estimated to plant additional 4.491 million saplings covering 2,181 ha by the end of 2 nd phase (Table 4).

ii) Replacement of lost forestland

- The forestland belongs to the Ministry of Forestry and Environment (MoFE) and the proponent is the Ministry of Culture, Tourism and Civil Aviation. As per the Forest Act, 1993 the proponent must pay cash compensation for the loss of forestland to MoFE as well as compensatory plantation for the loss of vegetation. EIA has suggested replacement of the lost land or cash compensation amounting to Rs 4.6 billion as well compensatory plantation of 61.27 million saplings covering 36,294 ha for the loss of 2.45 million trees in 7,582 ha of forest land; with total cost of Rs. 13.98 billion (Table 4).

\begin{tabular}{|l|l|l|l|}
\hline Description & SIA Phase 1 & $\begin{array}{l}\text { SIA full- } \\
\text { fledged } \\
\text { Phase I \& 2 }\end{array}$ & $\begin{array}{l}\text { SIA Project } \\
\text { area }\end{array}$ \\
\hline Saplings planted1/ & $\begin{array}{l}8.222 \text { mil- } \\
\text { lion }\end{array}$ & $\begin{array}{l}11.713 \text { mil- } \\
\text { lion }\end{array}$ & 61.27 million \\
\hline $\begin{array}{l}\text { Area requires (ha) } \\
\text { / }\end{array}$ & 5,139 & 7,320 & 36,294 \\
\hline $\begin{array}{l}\text { Plantation cost } \\
\text { (NPR) 3/ }\end{array}$ & 1.876 billion & 2.673 billion & 13.98 billion \\
\hline
\end{tabular}

1/ Considering 1:25 compensatory plantation; 2/ 1,600 saplings/ha; 3/NPR 365,00o/ha - includes plantation cost, watchman, replacement of dead trees and weeding management up to 5 years

Table 4: Area and cost of compensatory plantation

\section{iii) Other Measures}

- EIA has proposed protective, awareness and regulatory measures to reduce impacts of workforce and other visitors on local forest resources. These measures could discourage and control illegal entry to forest area or trapping/hunting wildlife or causing fire hazard in forest

- 'No horn' zone to be regulated on access road to airport for reducing noise level and disturbance to wildlife

- Adoption of ICAO guidelines and good practices to reduce Bird hazard

Comment: EIA does not include valuation of ecosystem services the forest area provides to the community $(7,487$ people) living in the project area and its adjacent area as well as just over 37,000 households living in downstream area who get direct benefit through collaborative forests and irrigation schemes.

Mitigation measures do not suggest any specific area for large scale compensatory plantation. Compensatory plantation program has been very weak in Nepal; plantations are either delayed or not complied with (Shah, 2004). A largescale compensatory plantation of this scale has not been done in Nepal. Even if plantation at this scale is done, it will not restore all kinds of ecosystem services provided by the current forest. All the species could not be practically planted, and moreover it takes many decades to build the species diversity and fully functioning forest ecosystem.

\section{c) Socioeconomic and Cultural Environment}

i) Displacement of people and Relocation of Settlement

- All households living in Tangiya basti, Matiyani and Kathghat settlements in the project area will be displaced. EIA estimates displacement of 7,487 people living in 1,492 households.

- These households will lose all their cultivated land (503 ha). They all are new settlers and do not possess landownership certificates.

- The three settlements Tangiya basti, Matiyani and 
Kathghat will be totally abandoned.

ii) Impact on water availability in indirect impact area

- The 7 irrigation schemes irrigating 2,688 ha in 15 settlements would be adversely affected; this would affect farm production

iii) Construction related social impacts

- This includes public health and sanitation of work force, occupational health and safety, epidemic, social disturbances etc

iv) Impact on Sahajnath temple located close to the proposed runway. Access to temple would be cut-off.

\section{Mitigation Measures}

i) Resettlement Plan

- EIA has proposed a Resettlement plan for the project affected households which includes modality for the compensation for the loss of private and community properties and service infrastructures. As per the existing law, government can pay compensation only to private landowners with land ownership papers. Cash compensation for the loss of residential or other buildings, built-in structures, standing crops, transportation and hardship and displacement costs, rehabilitation grants, business loss has been suggested. Project affected people preferred 'land for land' compensation.

ii) Relocation of Sahajnath temple for easy access to devotees has been proposed.

iii) EIA has proposed construction of office buildings of Tamagadi and Sahajnath Collaborative Forests.

Comments: EIA has not taken account of permanent settlers in Kathghat settlement who possess landownership certificates. EIA lacks livelihoods analysis of households living in the proposed project area and outside project area who depend on project forests for their livelihoods - forest products and water source for irrigation.

\section{ALTERNATIVE ANALYSIS}

An alternative analysis conducted for the EIA has suggested development of airport city at the south of the proposed project area by land pooling arrangement. There is no analysis done on the alternate site for SIA.

\section{DISCUSSION AND ACTION REQUIRED}

\section{Need for SIA}

Tribhuvan International Airport (TIA) in Kathmandu is highly congested and there is no space for its expansion due to haphazard urbanization and topographical limitations. Government is building 'Regional Airports' in Pokhara in a valley, and Bhairahawa in Madhesh plain area at the Indian border with loans from International agencies; Pokhara has topographical limitations for landing and take-off of large aircrafts. Currently TIA handles about 1.1-1.3 million passengers per year which is much less than required at present.
Nepal urgently needs a second International airport (SIA) which can handle increasing numbers of international passengers. Its need was realised in early 1990 and it has already been in planning for the last 24 years; prefeasibility study was done in 1995. The total cost estimated for full-fledged SIA with 60 million passengers per year capacity and airport city was US \$ 6,565 million in 2010; government decided to build SIA in 2007 but had no funds.

\section{Project Planning}

Feasibility studies are not ample: This proposed SIAP is still under conceptual planning and the EIA conducted as per national legislations could be regarded as 'preliminary environmental and social investigation'. EIA conducted as per Government of Nepal's rules and policy has outlined serious environmental and social implications but lacked in-depth study on wildlife, ecosystem services, effects of aircraft noise on wildlife including birds, and livelihoods of people living in SIA, host municipality and in "Indirect Impact Area" i.e. adjacent areas. EIA has not studied impacts of the proposed Airport City; no rationale is given for development of this city. People living in project area, project municipalities and adjacent areas are freely gaining benefits from the project area and forest ecosystems. Jet aircraft noise could have behavioural effects, habitat shift and change in feeding habit in wildlife and birds (Kempf and Huppop, 2014; Pepper et al., 2003).

Project Site: The proposed area lies in Terai Arc Landscape (TAL) which is extended from Parsa National Park to Suklaphanta National Park. The TAL program which aimed at landscape-scale conservation of tigers, rhinos and elephants was initiated in 2001 by the Government of Nepal with the collaboration of WWF Nepal (WWF, 2018). It focusses on restoring the wildlife corridors. Again, the project area is a neighboring landscape and buffer zone of Parsa National Park, frequently visited by elephants and other mammals. There are numerous human wildlife incidents reported in this location. Any impact study in the project area should also include Parsa National Park and or for longterm Terai Arc landscape.

Government has declared $80.46 \mathrm{sq} \mathrm{km}$ area of which 94.2\% is forest area, on the assumption that the future development of the 'second international airport (SIA)' will be an international hub for air traffic in South Asia and a possible 'defence airport' of the country (GEOCE, 2018). Size of airport facilities and airport utilities has been calculated on the assumption of handling 60 million passengers per year or $164,000 /$ day. Aviation experts are sceptical and argue that the whole international hub' concept is outdated and misplaced by proponent Ministry of Culture, Tourism and Aviation (Rai OA, 2018). Moreover, the concept of 'defence airport' in Nepal is questionable. The proposed airport site is at an 
aerial distance of $20 \mathrm{~km}$ from Indian border.

The present analysis indicate that the government must rethink its policy on SIA and discuss with concerned stakeholders including aviation experts, conservationists, and economic development planners. Strategic environmental and social assessment of policy and plan should be conducted prior to a comprehensive EIA of the project.

Biological and Livelihoods: The loss of 80.5 sq km buffer zone of Parsa National Park and Terai Arc Landscape - corridor to wildlife movement would have disastrous effects on wildlife. EIA indicated clearing of 1,641 ha forest vegetation for full-fledged airport construction and eventually clearing all forest area 75.8 $\mathrm{sq} \mathrm{km}$ for airport operation. This will be a great loss of wildlife habitat, biodiversity-rich Terai-hardwood forest ecosystem and collaborative forests which have been providing various ecosystem services including forest products and water for irrigation to a large population living in adjacent areas and south of SIA proposed site. This would adversely affect livelihoods of people including over 7,480 people who would be displaced. There is no rationale for clearing all the forest area which is against the national environmental policy of Nepal (GON, 1993).

Replacement of lost forests: EIA has suggested compensatory planting in 36,294 ha as replacement of lost forest. This is highly ambitious plan, unachievable in Nepal's context. Moreover, EIA has not worked out sites and modality of plantation. It would take decades to regenerate similar habitat of equivalent ecological value in different location.

Planning for Airport City: SIA project includes development of an Airport City spread in $6 \mathrm{sq} \mathrm{km}$ area adjacent to airport. There is no rationale for developing a city very close to airport at the cost of biodiversity rich forest area. It is also not advisable to limit the size of a city. Nijgadh town in Nijgadh municipality is located about 5-6 km from SIA site in Kohalbi municipality and government is preparing Smart City Master Plans for four urban towns including Nijgadh (Jha KK, 2018). Nijgadh municipality has an area of $157 \mathrm{sq} \mathrm{km}$ and its population as per 2011 is 35,403 .

Costs estimate and international standards: The detailed feasibility study in 2010 estimated US \$ 545 million as cost for the 1st phase and US $\$ 6,565$ million as the total cost in three phases. Assuming 6-7\% inflation rate, project cost in 2019 would be around US $\$ 900$ million for phase 1 and US $\$ 10-11$ billion as total project cost. It is a huge sum of money for Nepal. Government must look for international financial and multilateral development agencies (for example, the World Bank group, ADB). These agencies have stringent
'Environmental and Social Sustainability' requirements and full-fledged ESIAs are required for loans (IFC, 2012; IFC, 2007; ADB, 2009).

EIA Report approval for implementation: Local Consultant GEOCE prepared EIA Report based on TOR approved by then Ministry of Environment in 2011 and submitted to the Proponent MoCTA in March 2018. Despite technocratic problem in EIA report viz. informational weakness, insufficient analysis of impacts and inadequately proposed mitigation measures, Ministry of Forest and Environment approved the EIA Report in the last week of may 2018, just about 2 months from the date of report received. In general, approval of EIA report for implementation takes at least 6 monts 9 months from the date of receipt (author's personal experience). This indicates strong political influence on EIA as both proponent and the EIA approval agencies belong to government. Government commenced land acquisition in August 2016 for SIA construction, 2 years before EIA approval which shows that government is keen to implement this SIA project for some unknown or hidden reason. It indicates that it is using EIA as an exercise in 'pro forma compliance' with legal requirements. Proponent has already made arrangement with Nepal army to clear fell trees long before guarantee of fund for SIA construction. It supports the convention that politically motivated EIAs of infrastructure projects are becoming common in developing countries where environmentalism is at infancy.

\section{Action Required}

Action required - for sound decision making for airport development and economic growth in tourism and related development sectors.

Delay in the construction of a 'Second International Airport' would be disastrous on tourism growth and development as well as the overall economic growth of the country. International connectivity must be enhanced soon. Government must make vital wise-decisions on: i) size of airport facilities - is 60 million passengers per year required? - needs intensive stakeholder consultation with aviation expetrs, conservations, environmental planner, economists and local community.

ii) 'Airport City' covering 600 ha - is it required when government is spending huge money for Smart City planning in Nijgadh Municipality, about 5-6 km from the proposed site?

iii) preparation of Detailed Project Report within a year with detailed cost estimates

mission for financial resources - requesting International Financing/Lending agencies; even the 1st phase SIA construction would cost around US $\$ 1$.0 billion at the current price, and

no any forest clearance until financial resources are assured and a comprehensive ESIA is prepared and approved both by a lending agency and the 
government of Nepal.

There are international environmental guidelines and standard for airport infrastructure development and its sustainable operation (ICAO, 2009, IFC, 2007). A comprehensive ESIA will describe environmental and social resources, identify project impacts and cumulative impacts, recommend appropriate mitigation measures for each identified positive and adverse impacts, and outline their implementation strategy, both in 'Direct Impact Area' and 'Indirect Impact Area'. It would analyse alternatives for airport infrastructure components and their sites and help decision-makers to make their final approval for project implementation.

Shree Govind Shah, PhD, Ecologist, Environmental Planning and Policy Analyst, has just over 30 years of work experience in the field of environmental planning and assessment, natural resource management, ESIA and environmental and social safeguards of infrastructure projects (hydropower, irrigation, roads, ocean cruise terminal, transmission line etc) and development projects (agriculture, livestock, forestry, tourism etc) and forest and wildlife biodiversity assessment in Nepal, Bhutan, Victnam, Combdia, Uganda and Indonesia. Visiting Professor at Faculty of Environmental and Biological Sciences, Kathmandu University, Nepal in 1999-2003. Visiting scholar at Faculty of Political Theory and Policy Analysis, Indiana University, U.S.A., 1996.

Corresponding address: sgs.erma.np@gmail.com

\section{Referances}

ADB (2009) Safeguard Policy Statement. Asian Development Bank, June 2009.

Cashmore, M, R Gwilliam, R Morgan, D Cobb and A Bond 2004. The interminable issue of effectiveness: substantive purposes, outcomes and research challenges in the advancement of environmental impact assessment theory. Impact Assessment and Project Appraisal, 22(4), December, 295-310.

Devlin John F and Nonita T Yap and Bob Weir (2005) Public participation in environmental assessment case studies on EA legislation and practice. Canadian Journal of Development Studies. 26 (3) September 2005, 487-500.

GEOCE(2018) Environmental Impact Assessment (EIA) of Second International Airport Project. GEOCE Consultants Pvt (Ltd), March 2018, Kathmandu, Nepal

GON (1993) Nepal Environmental Policy and Action Plan: Integrating environment and development. Environment Protection Council, Government of Nepal. August 1993, Kathmandu Nepal.

GON (1997). Environmental Protection Act, 1997. Ministry of Population and Environment (English Translation). Pages 11.
GON (19971). Environmental Protection Rules, 1997. Ministry of Population and Environment (English Translation). Pages 12-71.

GON (2001) Forest Rules, 1995 with its revision in 2001, Government of Nepal

GON (2018) Kolhabi Municipality, December 2018, Nepal. http://www.kolhabimun.gov.np/en

Hakakhaki (Sept 2018) Forest Ministry's position on Nijgadh Int'l Airport a welcome step. Hakahaki, 12 September 2018, Kathmandu, Nepal. http://www. hakahakionline.com/en/4926/forest-ministrysposition-on-nijgadh-intl-airport-a-welcome-step/

Hironaka, Ann (2002). The globalization of environmental protection: the case of environmental impact assessment. International Journal of Comparative Sociology (de Sitter), 43(1), 65-78.

IAIA (1995) Impact Assessment. Vol 13 No. 1, Spring 1995. International Association for Impact Assessment

ICAO (2009) Airport planning, design, operation and safety. ICAO Annex 14 Volume I - Aerodrome Design and Operations, 5th Edition. International Civil Aviation Organisation (ICAO). https://aci.aero/ Media/aci/file/ACI_Priorities/Safety/ACI_Policies_ and_Recommended_Practices_seventh_edition_5. pdf

IFC (2007) Environment, Health and Safety Guidelines for AIRPORTS. International Finance Cooperation (IFC), World Bank Group, 30 April 2007

IFC (2012) Performance Standards on Environmental and Social Sustainability. International Finance Cooperation (IFC), World Bank Group, 1 January 2012

IUCN (2008) IUCN Red list of threatened species WWW. iucnredlist.org.

Jha, K Kishore (2018) Regional Context of Smart City Development - the case of Province 2, September 2018, Kathmandu, Nepal.

KP (2018) EIA Report of Nijgadh Int'l Airport Approved. KathmanduPost, 24 May 2018

http://kathmandupost.ekantipur.com/news/2018-0524/eia-report-of-nijgadh-intl-airport-approved.html

Norbert Kempf and Ommo Huppop (2014) The Effects of Airport Noise on Wildlife: A Review and Comment. https://www.researchgate.net/ publication/248038212_The_effects_of_aircraft_ noise_on_wildlife_A_review_and_comment

Pepper CB1, Nascarella MA, Kendall RJ. (2003) A review of the effects of aircraft noise on wildlife and humans, current control mechanisms, and the need for further study. Environ Manage. 2003 Oct;32(4):418-32. https://www.ncbi.nlm.nih.gov/pubmed/14986892

Rai, Om Astha (2018) Does Nepal need a 4th International Airport? Nepal Times, 1 June 2018, Kathmandu, Nepal. https://www.nepalitimes.com/banner/doesnepal-need-a-4th-international-airport/

Robinson, N A (1992) International trends in environmental impact assessment. Boston College 
Environmental Affairs Law Review, 19(3), Spring, 591-622.

Shah, SG (2004) Environmental Performance of Kaligandaki 'A' hydroelectric Project, ADB, Kathmandu, December 2004.

THT (Sept 2018) 763,480 trees to be cut for Nijgadh airport. The Himalayan Times, 16 September 2018, Kathmandu, Nepal. https://thehimalayantimes. com/business/76348o-trees-to-be-cut-for-nijgadhairport/

van de Grondane (1994) "Use and Effectiveness of Environmental Impact Assessment in Decision Making”. Report of a pilot study by BCR Consultants, Rotterdam, the Netherlands, 25 May 1994.

WB (2016) Environmental and Social Policies. World Bank, August 2016

WWF (2017) Terai Landscape (TAL). WWF, Kathmandu, Nepal 2017. http://www.wwfnepal.org/about_wwf/ where_we_work/tal/ 